Egyptian J. of Nutrition Vol. XXXV No. 1 (2020)

\title{
Utilization of green pumpkin in processing some nutritional products
}

\author{
Ghada H. H.Ismaiel and Hala M. Z. Ali
}

Food Technology Research Institute, Agricultural Research Center, Giza , Egypt.

\begin{abstract}
This study aimed to utilize green pumpkin in processing some traditional products. A raw leaves and fruits pumpkin were obtained from Horticulture Research Institute. Food technology practices such as making of jam, budding, pickles and cooking of the leaves and fruittoperformed in these pumpkin products. To assess the impact of food technology practices on some chemical and biological characteristics of pumpkin as well as antioxidant activity. For this purpose, some parameters such as sensory evaluation, chemical composition, macro andmicro-nutrients content, antioxidant activity, antimicrobial activity, phenolic acid compounds and flavonoid compounds of pumpkin were determined in these samples. The important obtained results were summarized as follows:
\end{abstract}

The total acceptability of pumpkin products took the descending order: apricot + pumpkin jam $(1: 1)>$ pumpkin pickles >pumpkin budding. The highest value of potassium, calcium, sodium, Iron and zinc were realized by pumpkin fruits pickles. Total phenols and total flavonoid as well as caroteins and chlorophyll $A$ and $B$ wereachieved higher values in pumpkin leaves than those obtained in pumpkin fruits. Higher values of antimicrobial activity were realized 
by pumpkin leaves than realized in pumpkin fruits against Bacillus ceries and Salmonella cyphimurium. On the other hand, pumpkin fruits achieved more pronounced values of antimicrobial activity than those achieved in pumpkin leaves against Escherichia coli and Staphylococcus aurous.

It was found that the major compound of phenolic acid in pumpkin leavesandfruits was pyrogallol. Moreover, the major compound of flavonoid in pumpkin leaves as $\mathrm{mg} / 100 \mathrm{~g}$ was Hespirtin (33.39), followed by Hespirdin (28.91). However, Hespirdin (60.81) was the major compound of flavonoid in raw pumpkin fruit, followed by Quercetrin (23. 35). Therefore concluded using the pumpkin leaves and fruit in food technology practices to utilizing of them in health.

\section{Introduction}

Cucurbitacea have been known for almost 10,000 years. They can be used for multiple purposes, they are suitable for human and animal consumption, their nutritional and dietetic values are high - all these account for their widespread popularity. The usefulness of pumpkin was appreciated in all ages and accordingly it was regarded important not only as a food crop. Today shelled pumpkin seed has become widely known as a medicinal and functionally healthpreserving food crop (Madai , 2008).

Lagenaria siceraria (Mol.) Standl. (bottle gourd), of the family ucurbitaceae, is a climbing perennial plant widely cultivated as a vegetable crop in ropical countries, such as India, Japan and Thailand. Fruits of which are widely used in Ayurveda and other folk medicines traditionally used for its cardioprotective, cardiotonic, general tonic, diuretic, aphrodisiac, antidote to certain poisons and 


\section{Egyptian J. of Nutrition Vol. XXXV No. 1 (2020)}

scorpion strings, alternative purgative, cooling effects.It cures pain, ulcers and fever and used for pectoral cough, asthma and other bronchial disorders-especially syrup prepared from the tender fruits. The fruit is reported to contain the triterepeniode cucurbitacins $B, D$, G, $H$ and 22-deoxy cucurbitacin "the bitter principle of cucurbitaceae",two sterols i.e. fucosterol and mpesterol, aer penebyonolic acid Lagenaria siceraria is a well-known plant used in the Indian system of medicine, besides which folklore medicine also claims its uses especially in cardiac and hepatic diseases, ulcer, etc. L. cerariafruit is cultivated in India, Japan, Sri Lanka, China, Thailand for its vegetable use. This fruit is the source of 'Dudhi Bhopala Juice', which is used as a supplement to the treatment of cardiac diseases( Upaganlawar and Ramchandran, 2009).The fruits are edible and considered as a good source of vitamin $C, \beta$-carotene, vitamin Bcomplex, pectin and also contain highest choline level - a lipotropic factor (Rahman, 2003).

Lagenaria siceraria (Molina) Standl.is a vegetable food also used as a traditional medicine. It is reported to have immunomodulatory, hepatoprotective, cardioprotective, antioxidant, anti-stress and adaptogenic, antihyperlipidemic, analgesic, and antiinflammatory properties. A novel protein, Lagenin, isolated from seeds is reported to have antitumor, antiviral, antiproliferative, and anti-HIV activities. The consumption of bottle gourd can be considered to improve human health (Irfan Ahmad 2011).

Fruits are reported to contain more soluble dietary fibers than insoluble cellulose fibers (Ghuleetal., 2006).The fruits are considered as good source of vitamin C, $\beta$-carotene, vitamin B-complex, pectin and also contain highest choline level-a lipotropic factor(Duke ,2006). 
Ghada H. H.Ismaiel and Hala M. Z. Ali

Pumpkin fruits are sweet when ripe with yellow or orange flesh rich in $\beta$-carotene, a precursor of vitamin A. Pumpkin is a rich source of functional food components like vitamins, minerals and dietary fibers. Pumpkin can profitably be converted into a variety of value added products such as jam, jelly, marmalade, candy, puree, sauce, chutney, pickle and halwa. Pumpkin flour could be used to supplement cereal flours in bakery products, soups, instant noodles and natural colouringagent in pasta and flour mixes. 1,1-diphenyl-2picryl-hydrazyl (DPPH) test was used for determination of the radical scavenging activity. Within the group of volatile compounds, the dominant component in the fruit was heneicosane (46.5\%), followed by benzaldehyde, tricosane, eicosane and pentacosane. Mostly represented of the leaf were (46.2\%), nonadecane, benzaldehyde, as well as terpenes $(E)$ - $\beta$-damascone and $(E)$ - $\beta$-ionone. Among the volatiles of the seed, heptadecane $(22.3 \%)$, etradecane, octadecane, hexadecane, tridecane and benzaldehyde were the most abundant (Difco- Manual , 1998).

\section{Aim of this investigation :}

Green pumpkin as for as leaves and fruits contain important of vitamin, phenol, minerals and many of bioactive constants, whereasthis study aimed to utilize of green pumpkin ( leaves and fruits) in processing some traditional products of health to assess the impact of food technology practices on some chemical and biological characteristics of pumpkin as well as antioxidant and antimicrobial activities . 
Egyptian J. of Nutrition Vol. XXXV No. 1 (2020)

\section{Materials and Methods}

\section{Materials:}

Plant materials

Fruits and leaves of green pumpkin (Lagenaria siceraria L.) were collected from the Horticulture Research Institute ( HRI ) in Egypt and wash, cut into small spices and oven dried at $50^{\circ} \mathrm{C}$ over night. All raw material used for processing of pumpkin products brought of local market.

\section{Methods:}

Preparation of new pumpkin products as cooked leaves, pickles, pumpkinfruits jam ,pumpkin fruits Jam Apricot + pumpkin fruits Jam (1:1), Pumpkin fruits buddingand cooked pumpkin fruits are illustrated in Table (1).

\section{Sensory evaluation}

Sensory evaluation of samples were evaluated by 10 panelists. Sensory characteristics of samples; appearance, color , odor, texture, taste, and overall acceptability were evaluated according to Worrasinchaiet al.(2006).

Chemical composition such as moisture, ash content, crude protein, crude fiber, total lipidand mineral content of fruits and leaves of green pumpkin and its products were determined according to the methods of A.O.A.C. (2005).

\section{In vitroantioxidant study:}

Total phenolics and flavonoids were determined according to the method described by (Singleton and Slinkard,1977). Carotenoids were determined as described by Wettstein (1957) .Chlorophyll content (A and $B$ ) in the powdered dried of fruits and 
Ghada H. H.Ismaiel and Hala M. Z. Ali

leaves of green pumpkinand its productswere determined according to the method described by (Arnon ,1949).

Separation and identification of chemical components of the extracted dried powdered of fruits and leaves of green pumpkin by HPLC:

HPLC Agilent 1200 series equipped with quaternary pump, Auto sampler, column compartments ET at $35^{\circ} \mathrm{C}$, malti wavelength detector set at $330 \mathrm{~nm}, 280 \mathrm{~nm}$ for detection of flavonoid compounds and phenolic compounds, degasser, column used for fractionation Zorbax OD. $4.6 \times 250 \mathrm{~mm}$ and the flow rate of mobile phase during run was $1 \mathrm{ml} / \mathrm{min}$.

\section{HPLC analysis of phenolic compounds :}

The phenolic compounds of the powdered dried of fruits and leaves of green pumpkin and its products in methanolic extract were fractionated and identified by HPLC according to the method described by Goupyet al. (1999).

\section{HPLC analysis of flavonoid compounds :}

Flavonoid compounds of the powdered dried of fruits and leaves of green pumpkinand its products in methanolic extract according to the method described by Mattilaet al. (2000).

\section{Antimicrobial activity:}

\section{Used media for antimicrobial activity :}

The Mueller Hinton, sabouraudagar media and Nutrient broth were used in the disc diffusion technique for antibacterial assays according to Difco- Manual (1998). The antimicrobial activity of fruits and leaves of green pumpkin methanolic extracts were determined by the disk diffusion methods(Bauer et al., 1966). 


\section{Egyptian J. of Nutrition Vol. XXXV No. 1 (2020)}

\section{Bacterial strain :}

Four bacterial strains of significant importance were used to test the antibacterial properties of fruits and leaves of green pumpkin extracts. Two of them were gram positive (Bacillus cereus ATCC6538 and Staphylococcus aureus ATCC25923) and the others were gram negative ( $E$. coli ATCC25922 and Salmonella typhimurium ATCC9027). The cultures of strains used in this study were obtained from microbiological Resources Centre (MIRCEN), Faculty of Agriculture, Ain Shams University, and Cairo, Egypt. Bacterial strains were inoculated into Mueller Hinton broth (Difco) and incubated at $37^{\circ} \mathrm{C}$ for $24 \mathrm{~h}$. The cultures were subjected to three successive $24 \mathrm{~h}$. transfers before use. All cultures were adjusted to $106 \mathrm{CFU}$ per $\mathrm{ml}$.

\section{Disk diffusion assay:}

Five milliliter of Muller Hinton agar was placed into $10 \mathrm{~mL}$ petridishes and $0.1 \mathrm{~mL}$ of the active cultures was spread over the plate using a sterile glassspreader in order to get a uniform microbial growth for all plates (Bauer et al., 1966).

\section{Microbiological assays:}

Microbiological analysis of green pumpkin products were analyzed by microbiological tests including bacteria and yeast \&mold, at zero time ,4,8 days for (cooking pumpkin) and at zero time,6,12 month for (jams \& pickles) of storage at refrigerator $5^{\circ} \mathrm{C}$ and room temperature $25^{\circ} \mathrm{C}$ respectively. All analyses were determined according to A.O.A.C (2000).

\section{Statistical analysis}

The obtained data were exposed analysis of variance. Duncan's Multiple range tests at $(p \leq 0.05)$ level was used to compare 
Ghada H. H.Ismaiel and Hala M. Z. Ali

between means. The analysis was carried out using the PROANOVA procedure of Statistical Analysis System (SAS, 1996).

\section{Results and Discussion}

\section{Sensory evaluation of pumpkin products.}

The results in Table (2) cleared that sensory evaluation of pumpkin as affected by food technology practices. The highest significant difference was achieved in color of pumpkin pickles, followed by apricot pumpkin jam $(1: 1)$ as well as pumpkin budding. Although the lowest one was observed in cooked pumpkin leaves.

On the other hand, the maximum significant difference of odor was realized in both pumpkinpickles and apricot + pumpkin jam (1:1), followed by pumpkin budding pumpkin jam. While, the highest score of texture was achieved in each apricot + pumpkin jam (1:1) and pumpkin budding, followed by pumpkin jam and cooked pumpkin fruits.

The total acceptability of pumpkin productstook the descending order: apricot + pumpkin in jam $(1: 1)>$ pumpkin pickles $>$ pumpkin budding $>$ cookedpumpkin fruits and pumpkin jam >cooked pumpkin leaves.

\section{Chemical composition of pumpkin and the products:}

The obtained results in Table (3) revealed that higher contents of Ash, and protein were achieved in cooked pumpkin leaves over those obtained in raw pumpkin leaves. Although raw pumpkin leaves realized higher values of carbohydrates than obtained in cooked pumpkin leaves. On the other hand, the effect of valuefood technology practiceson chemical composition of pumpkin fruits appeared that the maximum value of ash was resulted in 
Egyptian J. of Nutrition Vol. XXXV No. 1 (2020)

cooked pumpkin leaves, followed by raw pumpkin leaves and cooked pumpkin fruits, The highest value of fat was occurred in pumpkin budding, followed by cooked pumpkin fruits.

The optimum value offiberwere realized in raw pumpkin fruits as well as pumpkin fruits pickles. Additionally, the maximum value of protein was obtained by cooked pumpkin fruits and pumpkin fruits pickles, Table(3). On the other hands, pumpkin fruits budding achieved the highest value of carbohydrates, followed by pumpkin fruits Jam and apricot + pumpkin fruits Jam (1:1). However, the lowest one was obtained by cooked pumpkin leaves.

\section{Macro and micro-nutrients of pumpkin( $\mathrm{mg} / 100 \mathrm{~g}$ ) as affected by food technology practices:}

The result in Table (4) cleared that higher values of potassium and calcium contents were realized by pumpkin fruits pickles, followed by raw fruits pumpkin. However, the lowest value of potassium and calcium were achieved by pumpkin fruitsbudding. On the other hand, pumpkin fruits pickles gave the highestvalue of sodium. While, pumpkin fruits budding achieved the least one. Whereas, the maximum values of iron and zinc were obtained by pumpkin fruits pickles. But, pumpkin fruits budding achieved the minimum values of $\mathrm{Fe}$ and $\mathrm{Zn}$.

Adversely, the highest value of Selinium (Se) was achieved by pumpkin fruits budding. While, the lowest one was obtained by pumpkin fruits pickles. These results are an accordance with the obtained by Dhimanet al., (2009). 
Ghada H. H.Ismaiel and Hala M. Z. Ali

Antioxidant activity of pumpkin products as effected by food technology practices:

The obtained results in Table (5) revealed that antioxidant activity of pumpkin, e.i, total phenols, total flavonoids, caroteins and chlorophyll contents of pumpkin are illustrated in Table (5). It was found that total phenols obtained inpumpkin leaves was higher than those obtained in pumpkin fruits. On the other hand the maximum value of total phenols was achieved in raw pumpkin fruits, followed by pumpkin fruits budding. While, the lowest one achieved in pumpkin fruit jam.

Similarly, total flavonoid values realized in pumpkin leaves were more pronounced than those obtained in pumpkin fruits. Additionally, cooked pumpkin fruits achieved highest value of total flavonoids, followed by pumpkin fruits pickles. However, the lowest one was achieved in pumpkin fruits jam. The results in Table (5) also displayed that the highest values of caroteins were achieved by each of raw pumpkin leaves, raw pumpkin fruits as well as pumpkin fruits pickles. However, pumpkin fruits budding had the lowest one. Concerning chlorophyll A, B, Data in Table (5) revealed that raw pumpkin leaves gave the maximum values of chlorophyll $A$ and $B$ followed by raw pumpkin fruits. Although, pumpkin fruits pickles as well as cooked pumpkin fruits achieved the lowest content ofchlorophyll A and B. These results are an agreement with those obtained by (Rahman, 2003 and Irfan Ahmad 2011).

Phenolic acid compounds of pumpkin products $(\mathrm{mg} / \mathrm{g})$ as affected by food technology practices:

Data in Table (6) appeared the phenolic compounds of pumpkin leaves and fruits as affected by food technology practices. The results showed that raw leaves of pumpkin achieved as 


\section{Egyptian J. of Nutrition Vol. XXXV No. 1 (2020)}

$\mathrm{mg} / 100 \mathrm{~g}$, Pyrogallol (809.5), Caffeine (286.2), Catechin $(200,1)$, Alpha-cumaric (188.4), Salicylic (183.3), 3,4,5 Methox (222.9), Caffeic (145.07) Oleuropein (101.77), 3-Hdroxytyrosol (80.5), PBenzoic (71.32), Chlorogenic (59.26), Cumaric (34.94), P-cumaric (34.36) and Vanillic (32.06). While, raw fruits of pumpkin realized Pyrogallet (320.15), catechin (111.97), 3, 4, 5 Methexy (53.04), 3Hdroxy tyrosol (47.81), Oleuropein (38.21), Caffeine (35.96), Alphacumaric (34.75), chlorogenic (33.22), Salicylic (30.07) and P-oHBenzoic (28.67).

However, pumpkin fruits pickles achieved Pyrogallol $(169,09)$, Chlorogenic (59.92), Salicylic (58.20), P-oH-Benzoic (49,07), Oleuropein (36.77), Caffeine ( 34.87), Protocotchouic (31.79), Ferulic (36.63) and Ellagic (24.66). The results in Table (6) revealed that pumpkin fruits jam obtained that Pyrogallol (77.95), Catechin (34.08) Caffeine (14.15), Chlorogenic (10.95), Salicylict (7.07), Oleuropein (6.47), P-oH-Benzoic (7.96), Caffeic (5.55), 3-Horoxytyrosol (5.58)and Gallic (5.02) While, (apricot + pumpkin) Jam contained Pyrogallol (110.46), Iso-Ferulic (60.72), Oleuropein (34.02), Catechin (23.41), Caffeine (12.38),3-Hdrexytyrosol(12.16), 4-Aminobenzoic (8.33), Alpha-cumaric (7.82).

Whereas the major phenolic acid compound of pumpkin budding was Pyrogallol (35.03), it followed by protocatchouic (5.79) and Oleuropein (2.72). On the other hand, cooked pumpkin fruitachieved Pyrogallol (102.04), Caffeine (8.99), Catechin (7.89), chlorogenic (5.88), Oleuropein (6.98), Caffeic (4.48), Protocatchouic (4.29), Alpha-cumaric (4.12) and Salicylic (15.27). From the obtained results, it was noticed that the major compound of phenolic acid in pumpkin raw leaves and fruits were Pyrogallol, followed by Catechin. 
Ghada H. H.Ismaiel and Hala M. Z. Ali

Flavonoid compounds of pumpkin products $(\mathrm{mg} / \mathrm{g})$ as effected by food technology practices.

Data in Table (7) cleared flavonoid compounds of pumpkin leaves and fruits as affected by food technology practices.

It was found that the major compound of flavonoid in pumpkin raw leaves as $\mathrm{mg} / \mathrm{g}$ was Hespirtin (33.39) followed by Hespirdin (28.91) and Apegenin (26.95) While, cooked leaves of pumpkin contained Hespirdin (43.15), Quercetrin (14,92), Rutin (7.86), Kaempterol (7.68), Naringin (7.15) and Hespirtin (3.47). On the other hand, the major compound of flavonoid in pumpkin raw fruits was Hespirdin(60,81), follows by Quercetrin (23.35), Hespirtin (17.6), Quercitin (11.07), Rutin (5.48) and Naringin (5.47). It was noticed that food technology practices markedly affected on flavonoid compounds of pumpkin. Therefore, the major compound offlavonoid of pumpkin pickles was Hespirdin (21.66),followed byQuercetrin (16.41), Quercitin (8.61), Naringin (4.09), Hespirtin (2.967) and Apegenin (2.05).

Similarly, the major compound of flavonoid in pumpkin Jam, (apricot \& pumpkin) Jam and pumpkin budding were Hespirdin (19.09), Hespirolin (45.56) and Hespirdin (38.4) mg/g, respectively. Whereas, it followed by Quercetrin (16.35), Quercetrin (19.62) and Quercetrin (10.5) mg/g and followed by Rutin (4.9), Rutin (6.9) and Rutin (7.9) mg/g in pumpkin Jam, (apricot + pumpkin) Jam and pumpkin budding, respectively, Table(7). In this respect, the highest flavonoid compound of cooked pumpkin fruits was Hespirdin (52.85) $\mathrm{mg} / \mathrm{g}$, followed by Quercetrin (14.59), Rutin (6.56) and Naringin (3.15) $\mathrm{mg} / \mathrm{g}$. From aforementioned results, it could be concluded that pumpkin leaves and fruits can be considered as antimicrobial andantioxidant. Because pumpkin leaves and fruits included total 
Egyptian J. of Nutrition Vol. XXXV No. 1 (2020)

phenols total falvonoids, caroteins, chlorophyll $A$ and $B$. Moreover, it contained potassium, calcium, iron and zinc. For these reasons we can be recommended to utilize pumpkin products such as cooked pumpkin leaves, pumpkin fruit pickles, pumpkin fruit jam and/or pumpkin fruit budding.

\section{Antimicrobial activity of pumpkinfruits and leaves.}

Antimicrobial activity of pumpkin was performed against four bacteria strains,e.i., Bacillus ceries, Escherichia coli, Staphylococcus aurous and Salmonella cyphimurium. The results in Table (8) cleared that pumpkin leaves extracted by methanol had higher values of antimicrobial activity than pumpkin fruits extracted by methanol against Bacillus ceries as compared with methanol control.

Data in Table (8) also displayed that higher values of antimicrobial activity were obtained in methanol pumpkin fruits over those obtained in methanol pumpkin leaves against Escherichia coli as compared with methanol control.Similarly, methanol pumpkin fruits realized more pronounced values of antimicrobial activity against Staphylococcus aurous than realized in methanol pumpkin leaves.

On the other hand, methanol pumpkin leaves achieved higher antimicrobial values than those obtained in methanol pumpkin Fruits against Salmonella cyphimurium.

\section{Microbiology effect of pumpkin products as affected by food technology practices:}

The obtained results in Table (9a) revealed that the highest value of total bacteria was achieved by cooked pumpkin Leaves at zero time, after 4 and 8 days. Concerning the total yeast and mold, data in Table (9a) cleared that the maximum count of yeast and mold 
Ghada H. H.Ismaiel and Hala M. Z. Ali

was obtained by cooked leaves at zero time. However, after 4 and 8 days, cooked pumpkin fruits achieved the maximum count of yeast and mold.

Data in Table (9b) revealed that the highest value of total bacteria was achieved by pumpkin fruit pickles at zero time. While, after 6 and 12 months, pumpkin fruit jam realized the optimum value of total bacteria. Regarding the total count of yeast and mold, the results in Table (9b) appeared that the maximum total count of yeast and mold was achieved by pumpkin fruit pickles at zero time and also after band 12 months. 
Egyptian J. of Nutrition Vol. XXXV No. 1 (2020)

\section{Conclusion}

The green pumpkin ( leaves and fruits) have a high antioxidant and antimicrobial activities, and the pumpkin products have a stabile of micro and macro-nutrients, therefore concluded using pumpkin (leaves and fruit) in food technology practices to utilizing of them in health. 
Ghada H. H.Ismaiel and Hala M. Z. Ali

Table (1):Recipes of pumpkin products :

\begin{tabular}{|c|c|c|c|c|c|c|}
\hline Recipes Products & $\begin{array}{l}\text { Cooked } \\
\text { leaves }\end{array}$ & $\begin{array}{l}\text { Pumpkin } \\
\text { fruits } \\
\text { pickles }\end{array}$ & $\begin{array}{l}\text { Pumpkin } \\
\text { fruits } \\
\text { Jam }\end{array}$ & $\begin{array}{l}\text { Apricot }+ \\
\text { pumpkin fruits } \\
\text { Jam (1:1) }\end{array}$ & $\begin{array}{l}\text { Pumpkin } \\
\text { fruits } \\
\text { budding }\end{array}$ & $\begin{array}{l}\text { Cooked } \\
\text { Pumpkin } \\
\text { fruits }\end{array}$ \\
\hline $\begin{array}{l}\text { Green pumpkin } \\
\text { leaves }\end{array}$ & $400 \mathrm{gm}$ & & & & & \\
\hline $\begin{array}{l}\text { Green pumpkin } \\
\text { fruits }\end{array}$ & & $1000 \mathrm{gm}$ & 1000 & 500 & $100 \mathrm{gm}$ & $1000 \mathrm{gm}$ \\
\hline Apricot & & & & 500 & & \\
\hline Sugar & & & 1250 & 1250 & $200 \mathrm{gm}$ & \\
\hline $\begin{array}{l}\text { Limon Juice } \\
\text { ( citric acid) }\end{array}$ & & $50 \mathrm{ml}$ & $60 \mathrm{ml}$ & $60 \mathrm{ml}$ & & \\
\hline Salt & $20 \mathrm{gm}$ & $80 \mathrm{gm}$ & & & & $20 \mathrm{gm}$ \\
\hline Tomato & & & & & & $500 \mathrm{gm}$ \\
\hline Chiken soup & $1000 \mathrm{ml}$ & & & & & $500 \mathrm{ml}$ \\
\hline Onion & & & & & & $80 \mathrm{gm}$ \\
\hline Black paper & & & & & & $3 \mathrm{gm}$ \\
\hline Corn oil & & & & & & $10 \mathrm{gm}$ \\
\hline Buffalo fat & $20 \mathrm{gm}$ & & & & & $20 \mathrm{gm}$ \\
\hline Garlic & $10 \mathrm{gm}$ & $10 \mathrm{gm}$ & & & & \\
\hline Acetic acid & & $40 \mathrm{ml}$ & & & & \\
\hline Buffalo Milk & & & & & $1000 \mathrm{ml}$ & \\
\hline Starch & & & & & $100 \mathrm{gm}$ & \\
\hline
\end{tabular}

Table (2): Sensory evaluation of pumpkin products as affected by food technology practices.

\begin{tabular}{l|l|c|c|c|c|c|c}
\hline Task & $\begin{array}{c}\text { Productive } \\
\text { kind }\end{array}$ & Taste & Color & Odor & Texture & $\begin{array}{c}\text { Appearan } \\
\text { ce }\end{array}$ & $\begin{array}{c}\text { Total } \\
\text { acceptability }\end{array}$ \\
\hline Leaves & $\begin{array}{l}\text { Cooked } \\
\text { pumpkin }\end{array}$ & $20.0^{\mathrm{A}}$ & $17.0^{\mathrm{D}}$ & $18.0^{\mathrm{C}}$ & $18.0^{\mathrm{C}}$ & $18.0^{\mathrm{B}}$ & $91.0^{\mathrm{E}}$ \\
\hline Fruits & $\begin{array}{l}\text { Pumpkin } \\
\text { pickles }\end{array}$ & $20.0^{\mathrm{A}}$ & $20.0^{\mathrm{A}}$ & $20.0^{\mathrm{A}}$ & $18.0^{\mathrm{C}}$ & $20.0^{\mathrm{A}}$ & $98.0^{\mathrm{B}}$ \\
\hline & Pumpkin Jam & $20.0^{\mathrm{A}}$ & $18.0^{\mathrm{C}}$ & $19.0^{\mathrm{B}}$ & $19.0^{\mathrm{B}}$ & $20.0^{\mathrm{A}}$ & $96.0^{\mathrm{D}}$ \\
\hline & $\begin{array}{l}\text { Apricot } \\
\text { pumpkin Jam } \\
(1: 1)\end{array}$ & $20.0^{\mathrm{A}}$ & $19.0^{\mathrm{B}}$ & $20.0^{\mathrm{A}}$ & $20.0^{\mathrm{A}}$ & $20.0^{\mathrm{A}}$ & $99.0^{\mathrm{A}}$ \\
\hline & $\begin{array}{l}\text { Pumpkin } \\
\text { budding }\end{array}$ & $19.0^{\mathrm{B}}$ & $19.0^{\mathrm{B}}$ & $19.0^{\mathrm{B}}$ & $20.0^{\mathrm{A}}$ & $20.0^{\mathrm{A}}$ & $97.0^{\mathrm{C}}$ \\
\hline & $\begin{array}{l}\text { Cooked } \\
\text { Pumpkin }\end{array}$ & $20.0^{\mathrm{A}}$ & $18.0^{\mathrm{C}}$ & $19.0^{\mathrm{B}}$ & $19.0^{\mathrm{B}}$ & $20.0^{\mathrm{A}}$ & $96.0^{\mathrm{D}}$ \\
\hline
\end{tabular}

Values followed by the same letters within the same coloum were not significantly different at 0.05 level 
Egyptian J. of Nutrition Vol. XXXV No. 1 (2020)

Table (3): Chemical composition of pumpkinproducts as affected by food technology practices (\%) .

\begin{tabular}{l|c|c|c|c|c|c}
\hline Task & Productive kind & Moisture & Ash & Fat & Fiber & Protein \\
\hline Leaves & Raw pumpkin & $10.69^{\mathrm{C}}$ & $16.20^{\mathrm{B}}$ & $2.67^{\mathrm{E}}$ & $11.57^{\mathrm{B}}$ & $5.25^{\mathrm{D}}$ \\
\hline & Cooked pumpkin & $12.14^{\mathrm{C}}$ & $19.69^{\mathrm{A}}$ & $5.73^{\mathrm{C}}$ & $10.99^{\mathrm{C}}$ & $15.63^{\mathrm{B}}$ \\
\hline Fruits & Raw pumpkin & $15.05^{\mathrm{B}}$ & $3.17^{\mathrm{E}}$ & $3.70^{\mathrm{D}}$ & $14.71^{\mathrm{A}}$ & $16.25^{\mathrm{B}}$ \\
\hline & Pumpkin pickles & $17.89^{\mathrm{B}}$ & $5.96^{\mathrm{D}}$ & $3.80^{\mathrm{D}}$ & $14.92^{\mathrm{A}}$ & $17.50^{\mathrm{A}}$ \\
\hline & Pumpkin Jam & $16.85^{\mathrm{B}}$ & $3.17^{\mathrm{E}}$ & $2.83^{\mathrm{D}}$ & $8.58^{\mathrm{D}}$ & $12.19^{\mathrm{C}}$ \\
\hline & $\begin{array}{c}\text { Apricot + pumpkin } \\
\text { Jam (1:1) }\end{array}$ & $19.85^{\mathrm{A}}$ & $1.93^{\mathrm{F}}$ & $4.52^{\mathrm{C}}$ & $8.27^{\mathrm{D}}$ & $11.83^{\mathrm{C}}$ \\
\hline & Pumpkin budding & $9.47^{\mathrm{E}}$ & $0.35^{\mathrm{G}}$ & $8.86^{\mathrm{A}}$ & $1.60^{\mathrm{E}}$ & $4.19^{\mathrm{E}}$ \\
\hline & Cooked pumpkin & $10.26^{\mathrm{D}}$ & $10.65^{\mathrm{C}}$ & $6.43^{\mathrm{B}}$ & $10.98^{\mathrm{C}}$ & $18.75^{\mathrm{A}}$ \\
\hline
\end{tabular}

Values followed by the same letters within the same coloum were not significantly different at 0.05 level.

Table (4):Macro and micro - nutrients of pumpkin products as affected by food technology practices $(\mathrm{mg} / 100 \mathrm{~g}$ ).

\begin{tabular}{l|c|c|c|c|c|c|c}
\hline Task & Productive kind & $\begin{array}{c}\text { Potassium } \\
(\mathrm{K})\end{array}$ & $\begin{array}{c}\text { Calcium } \\
(\mathrm{Ca})\end{array}$ & $\begin{array}{c}\text { Sodium } \\
(\mathrm{Na})\end{array}$ & $\begin{array}{c}\text { Iron } \\
(\mathrm{Fe})\end{array}$ & $\begin{array}{c}\text { Zinc } \\
(\mathrm{Zn})\end{array}$ & $\begin{array}{c}\text { Selienium } \\
(\mathrm{Se})\end{array}$ \\
\hline Leaves & Raw pumpkin & $270.0^{\mathrm{C}}$ & $15.6^{\mathrm{A}}$ & $100.0^{\mathrm{E}}$ & $0.25^{\mathrm{A}}$ & $0.006^{\mathrm{D}}$ & $0.006^{\mathrm{B}}$ \\
\hline & $\begin{array}{c}\text { Cooked } \\
\text { pumpkin }\end{array}$ & $320.0^{\mathrm{B}}$ & $1.32^{\mathrm{B}}$ & $380.0^{\mathrm{C}}$ & $0.17^{\mathrm{B}}$ & $0.017^{\mathrm{A}}$ & $0.0023^{\mathrm{D}}$ \\
\hline Fruits & Raw pumpkin & $330.0^{\mathrm{B}}$ & $1.84^{\mathrm{B}}$ & $200.0^{\mathrm{D}}$ & $0.25^{\mathrm{A}}$ & $0.006^{\mathrm{D}}$ & $0.002^{\mathrm{D}}$ \\
\hline & Pumpkin pickles & $490.0^{\mathrm{A}}$ & $10.09^{\mathrm{A}}$ & $850.0^{\mathrm{A}}$ & $0.29^{\mathrm{A}}$ & $0.022^{\mathrm{A}}$ & $0.002^{\mathrm{D}}$ \\
\hline & Pumpkin Jam & $65.0^{\mathrm{E}}$ & $0.73^{\mathrm{C}}$ & $20.0^{\mathrm{G}}$ & $0.13^{\mathrm{B}}$ & $0.013^{\mathrm{B}}$ & $0.0025^{\mathrm{D}}$ \\
\hline & $\begin{array}{c}\text { Apricot + } \\
\text { pumpkin Jam } \\
(1: 1)\end{array}$ & $120.0^{\mathrm{D}}$ & $2.08^{\mathrm{B}}$ & $580.0^{\mathrm{B}}$ & $0.15^{\mathrm{B}}$ & $0.008^{\mathrm{C}}$ & $0.003^{\mathrm{C}}$ \\
\hline & $\begin{array}{c}\text { Pumpkin } \\
\text { budding }\end{array}$ & $40.0^{\mathrm{F}}$ & $0.608^{\mathrm{C}}$ & $20.0^{\mathrm{G}}$ & $0.13^{\mathrm{B}}$ & $0.0058^{\mathrm{E}}$ & $0.0077^{\mathrm{A}}$ \\
\hline & $\begin{array}{c}\text { Cooked } \\
\text { pumpkin }\end{array}$ & $130.0^{\mathrm{D}}$ & $1.22^{\mathrm{B}}$ & $120.0^{\mathrm{F}}$ & $0.18^{\mathrm{B}}$ & $0.011^{\mathrm{B}}$ & 0.0000 \\
\hline
\end{tabular}

Values followed by the same letters within the same coloum were not significantly different at 0.05 level. 
Ghada H. H.Ismaiel and Hala M. Z. Ali

Table (5):Antioxidant activity of pumpkin products as affected by Food technology practices $(\mathrm{mg} / \mathrm{g})$.

\begin{tabular}{l|l|c|c|c|c|c}
\hline Task & Productive kind & $\begin{array}{c}\text { Total } \\
\text { Phenols }\end{array}$ & $\begin{array}{c}\text { Total } \\
\text { Flavonoids }\end{array}$ & Caroteins & $\begin{array}{c}\text { Cholorophl } \\
\mathrm{A}\end{array}$ & $\begin{array}{c}\text { Cholorophl } \\
\mathrm{B}\end{array}$ \\
\hline Leaves & Raw pumpkin & $4.97^{\mathrm{A}}$ & $2.06^{\mathrm{A}}$ & $0.07^{\mathrm{A}}$ & $0.197^{\mathrm{A}}$ & $0.25^{\mathrm{A}}$ \\
\hline & Cooked pumpkin & $5.53^{\mathrm{A}}$ & $2.46^{\mathrm{A}}$ & $0.002^{\mathrm{B}}$ & $0.005^{\mathrm{C}}$ & $0.004^{\mathrm{C}}$ \\
\hline Fruits & Raw pumpkin & $2.95^{\mathrm{B}}$ & $1.06^{\mathrm{B}}$ & $0.03^{\mathrm{A}}$ & $0.007^{\mathrm{B}}$ & $0.015^{\mathrm{B}}$ \\
\hline & Pumpkin pickles & $2.06^{\mathrm{B}}$ & $1.31^{\mathrm{B}}$ & $0.024^{\mathrm{A}}$ & $0.001^{\mathrm{D}}$ & $0.002^{\mathrm{C}}$ \\
\hline & Pumpkin Jam & $1.40^{\mathrm{C}}$ & $0.96^{\mathrm{C}}$ & $0.0079^{\mathrm{B}}$ & $0.008^{\mathrm{B}}$ & $0.006^{\mathrm{C}}$ \\
\hline & Apricot+pumpkin & $2.30^{\mathrm{B}}$ & $1.064^{\mathrm{B}}$ & $0.003^{\mathrm{B}}$ & $0.007^{\mathrm{B}}$ & $0.002^{\mathrm{C}}$ \\
\hline & Jam (1:1) & & & & & \\
\hline & Pumpkin budding & $2.70^{\mathrm{B}}$ & $1.07^{\mathrm{B}}$ & $0.001^{\mathrm{B}}$ & $0.004^{\mathrm{C}}$ & $0.002^{\mathrm{C}}$ \\
\hline & Cooked pumpkin & $1.90^{\mathrm{C}}$ & $1.80^{\mathrm{B}}$ & $0.01^{\mathrm{A}}$ & $0.001^{\mathrm{D}}$ & $0.002^{\mathrm{C}}$ \\
\hline
\end{tabular}

Values followed by the same letters within the same coloum were not significantly different at 0.05 level.

Table (6): Phenolic acid compounds of pumpkin products ( $\mathrm{mg} / \mathrm{g}$ )as affected by food technology practices.

\begin{tabular}{|c|c|c|c|c|c|c|c|c|}
\hline Task & $\begin{array}{l}\text { Row } \\
\text { leaves }\end{array}$ & $\begin{array}{l}\text { Cooked } \\
\text { leaves }\end{array}$ & $\begin{array}{l}\text { Row } \\
\text { fruits }\end{array}$ & $\begin{array}{c}\text { Pumpkin } \\
\text { fruits } \\
\text { pickles }\end{array}$ & $\begin{array}{l}\text { Pumpkin } \\
\text { Jam }\end{array}$ & $\begin{array}{c}\text { Apricot+ } \\
\text { pumpkin } \\
\text { Jam }\end{array}$ & $\begin{array}{l}\text { Pumpkin } \\
\text { budding }\end{array}$ & $\begin{array}{c}\text { Cooked } \\
\text { pumpkin } \\
\text { fruits }\end{array}$ \\
\hline Gallic & 6.23 & 8.39 & 8.79 & 27.35 & 5.02 & 6.53 & 1.59 & 22.15 \\
\hline Pyrogallol & 809.52 & 118.34 & 320.15 & 169.09 & 77.95 & 110.46 & 35.03 & 102.04 \\
\hline 4-Aminobenzoic & 25.47 & 9.45 & 19.92 & 25.61 & 1.70 & 8.83 & 0.61 & 1.02 \\
\hline 3-Hdroxytyrosol & 80.50 & 17.94 & 47.81 & 18.57 & 5.58 & 12.16 & 3.39 & 3.83 \\
\hline Prootocatchouic & 29.95 & 4.68 & 25.67 & 31.79 & - & 1.53 & 5.79 & 4.29 \\
\hline Catechin & 200.11 & 43.91 & 111.97 & 20.26 & 34.08 & 23.41 & 0.86 & 7.89 \\
\hline Chlorogenic & 59.26 & 15.81 & 33.22 & 59.92 & 10.95 & 6.73 & 0.56 & 5.88 \\
\hline Caffeine & 286.21 & 8.47 & 35.96 & 34.87 & 14.15 & 12.38 & 1.08 & 8.99 \\
\hline P-oH-Benzoic & 71.32 & 4.79 & 28.67 & 49.07 & 7.96 & 1.95 & 0.58 & 2.03 \\
\hline Caffeic & 145.07 & 29.22 & 18.16 & 23.34 & 5.55 & 6.03 & 0.33 & 4.48 \\
\hline Vanillic & 32.06 & 2.12 & 9.07 & 23.52 & 0.70 & 1.40 & 0.29 & 0.35 \\
\hline P-Cumaric & 34.36 & 1.36 & 18.32 & 23.75 & 2.44 & 1.56 & 0.09 & 0.55 \\
\hline Ferulic & 26.44 & 1.02 & 2.56 & 36.63 & 0.82 & 4.58 & 0.51 & 1.08 \\
\hline Iso - Ferulic & 9.78 & 0.81 & 1.50 & 4.71 & 0.29 & 60.72 & 1.63 & 0.55 \\
\hline Ellagic & 29.63 & 1.36 & 22.46 & 24.66 & 0.53 & 0.87 & 0.01 & 3.20 \\
\hline Oleuropein & 101.77 & 1.02 & 38.21 & 36.77 & 6.47 & 34.02 & 2.72 & 6.98 \\
\hline Alpha-Cumaric & 188.43 & 1.36 & 34.75 & 2.69 & 0.07 & 7.82 & 0.51 & 4.12 \\
\hline Benzoiic & 2.82 & 0.55 & 0.30 & - & - & - & 0.52 & 0.31 \\
\hline Salicylic & 183.33 & 27.96 & 30.07 & 58.20 & 7.07 & - & 0.14 & 15.27 \\
\hline 3,4,5,Methoxy & 222.89 & 13.86 & 53.04 & 11.36 & 2.34 & 0.01 & 0.00 & 10.28 \\
\hline Cumarin & 34.94 & 2.55 & 8.18 & 24.32 & - & - & 0.10 & 1.31 \\
\hline Cinammic & 5.85 & 0.61 & 0.62 & 1.96 & 0.25 & 1.30 & - & 0.18 \\
\hline
\end{tabular}


Egyptian J. of Nutrition Vol. XXXV No. 1 (2020)

Table (7) :Flavonoid compounds of pumpkin products $(\mathrm{mg} / \mathrm{g}$ ) as affected by food technology practices.

\begin{tabular}{l|c|c|c|c|c|c|c|c}
\hline Task & $\begin{array}{c}\text { Row } \\
\text { leaves }\end{array}$ & $\begin{array}{c}\text { Cooked } \\
\text { leaves }\end{array}$ & $\begin{array}{c}\text { Row } \\
\text { fruits }\end{array}$ & $\begin{array}{c}\text { Pumpkin fruits } \\
\text { pickles }\end{array}$ & $\begin{array}{c}\text { Pumpkin } \\
\text { Jam }\end{array}$ & $\begin{array}{c}\text { Apricot+ } \\
\text { pumpkin } \\
\text { Jam }\end{array}$ & $\begin{array}{c}\text { Pumpkin } \\
\text { budding }\end{array}$ & $\begin{array}{c}\text { Cooked } \\
\text { pumpkin } \\
\text { fruits }\end{array}$ \\
\hline Naringin & 7.197 & 7.150 & 5.470 & 4.090 & 5.270 & 4.830 & 4.120 & 3.150 \\
\hline Rutin & 2.830 & 7.860 & 5.480 & 1.740 & 4.900 & 6.900 & 7.900 & 6.560 \\
\hline Hespirdin & 28.910 & 43.150 & 60.810 & 21.660 & 19.090 & 45.560 & 38.400 & 52.850 \\
\hline Quercetrin & 12.530 & 14.920 & 23.350 & 16.410 & 16.350 & 19.620 & 10.500 & 14.590 \\
\hline Quercitin & 9.370 & 1.380 & 11.070 & 8.610 & 0.270 & 1.030 & 0.680 & 0.233 \\
\hline Hespirtin & 33.390 & 3.470 & 17.600 & 2.967 & 0.037 & 1.780 & 0.085 & 1.080 \\
\hline Kaempterol & 11.140 & 7.680 & 1.250 & 1.275 & 0.057 & 2.640 & 0.035 & 0.485 \\
\hline Apegenin & 26.950 & 0.389 & 1.780 & 2.050 & 0.317 & 0.438 & 0.160 & 0.102 \\
\hline Naringenin & 2.207 & 0.159 & 0.420 & 0.443 & 0.085 & 0.037 & 0.068 & 0.127 \\
\hline
\end{tabular}

Table (8):Antibacterial activity $(\mathrm{mm})$ of pumpkin fruits and leaves.

\begin{tabular}{l|c|c|c|c}
\hline samples & $\begin{array}{c}\text { Bacillus ceries } \\
(\mathrm{B})\end{array}$ & $\begin{array}{c}\text { Escherichia coli } \\
(\mathrm{E})\end{array}$ & $\begin{array}{c}\text { Staphylococcus } \\
\text { auraus(St) }\end{array}$ & $\begin{array}{c}\text { Salmonella } \\
\text { cyphimurium(S) }\end{array}$ \\
\hline $\begin{array}{l}\text { Extract of methanol } \\
\text { pumpkin fruits }\end{array}$ & 0.77 & 1.47 & 0.77 & 0.63 \\
\hline $\begin{array}{l}\text { Extract of methanol } \\
\text { pumpkin leaves }\end{array}$ & 1.75 & 1.30 & 0.45 & 1.10 \\
\hline Methanol control & 0.63 & 1.55 & 0.65 & 0.50 \\
\hline Water control & - & - & - & - \\
\hline
\end{tabular}

$B=$ Bacillus ceriesATEC 33018

$\mathrm{St}=$ Staphylococcus auraus DSU 2023

$\mathrm{E}=$ Escherichia coli ATCC 69337

$\mathrm{S}=$ Salmonella cyphimurium ATCC14028 
Ghada H. H.Ismaiel and Hala M. Z. Ali

Table (9-a) :Microbiology effect of pumpkin products as affected by food technology practices

\begin{tabular}{c|c|c|c|c|c|c}
\hline \multirow{2}{*}{ Time } & \multicolumn{2}{|c|}{ Zero time } & \multicolumn{2}{c|}{ After 4 days } & \multicolumn{2}{c}{ After 8 days } \\
\hline products & $\mathrm{B}(1-2)$ day & $\mathrm{Y}(3-5)$ day & $\mathrm{B}(1-2)$ day & $\mathrm{Y}(3-5)$ day & $\mathrm{B}$ (1-2)day & $\mathrm{Y}(3-5)$ day \\
\hline Cooked leaves & 2.079 & 1.602 & 4.977 & 2.00 & 5.00 & 3.00 \\
\hline $\begin{array}{c}\text { Cooked Pumpkin } \\
\text { fruits }\end{array}$ & 1.602 & 1.477 & 2.756 & 2.415 & 3.00 & $5.477 /$ \\
\hline $\begin{array}{c}\text { Pumpkin fruits } \\
\text { budding }\end{array}$ & 1.477 & $\mathrm{Nil}$ & 2.643 & 1.00 & 4.431 & 4.431 \\
\hline
\end{tabular}

Table (9-b): Microbiology effect of pumpkin products as affected by food technology practices

\begin{tabular}{l|c|c|c|c|c|c}
\hline \multirow{2}{*}{ Products Time } & \multicolumn{2}{|c|}{ Zero time } & \multicolumn{2}{c}{ After 6 months } & \multicolumn{2}{c}{ After 12 months } \\
\cline { 2 - 7 } & $\mathrm{B}(1-2)$ day & $\mathrm{Y}(3-5)$ day & $\mathrm{B}(1-2)$ day & $\mathrm{Y}(3-5)$ day & $\mathrm{B}(1-2)$ day & $\mathrm{Y}(3-5)$ day \\
\hline $\begin{array}{l}\text { Pumpkin fruits } \\
\text { pickles }\end{array}$ & 4.653 & 2.819 & 1.00 & 3.00 & Nil & 3.301 \\
\hline Pumpkin fruits Jam & 1.00 & Nil & 1.845 & 1.602 & 1.903 & 2.00 \\
\hline $\begin{array}{l}\text { Apricot + pumpkin } \\
\text { fruits Jam (1:1) }\end{array}$ & Nil & Nil & 1.00 & 1.00 & 1.00 & 2.699 \\
\hline
\end{tabular}

$\mathrm{B}=$ total count of bacteria by Log

$\mathrm{Y}=\boldsymbol{=}$ total count of yeast and mold by Log 
Egyptian J. of Nutrition Vol. XXXV No. 1 (2020)

\section{References}

AOAC (2000).

Official Methods of Analysis. $16^{\text {th }}$ ed. Association of Official Analytical Chemists International,Arlington, Virginia, U.S.A.

AOAC (2005).

Official Methods of Analysis of the Association of Official Analysis Chemists Revision 1, International 18th Ed. Washington D.C, U.S.A.

Arnon, D I . (1949).

Copper enzymes in isolated chloroplasts.Plantphysio; 24:115.

Bauer, A.W.; Kirby, W. M.; Sherris, J.C. and Turck, M. (1966). Antibiotic susceptibility testing by a standardized single disk method.AmJ.Clinical Pathology, 45:493-496.

Dhiman,1. A. K., Sharma K.D. and SurekhaAttri (2009).

Functional constituents and processing of pumpkin: J Food SciTechnol , 46(5), 411-417.

Difco- Manual (1998).

Culture Media and Ingredients, Dehydrated. 11th Ed. Pub. Difco Lab., Division of Becton Dickinson and Company. Sparks, Maryland, USA.

Duke J.A. (2006).

Handbook of Medicinal Herbs, CRC press, Washington D. C, 114. 
Ghada H. H.Ismaiel and Hala M. Z. Ali

Ghule B.V., Ghante M.H., Saoji A.N.andYeole P.G.(2006).

Indian Journal of Experimental Biology; 44:905-909.

Goupy, P.; M. Hugues, P. Biovin, and M.J. Amiot, (1999).

Antioxidant composition and activity of barley (Hordeumvulgare) and maltextracts and isolated phenolic compounds. J. Sci. Food Agric., 79: 1625-1634.

Irfan Ahmad, Md. Irshad, and M. Moshahid A. Rizvi(2011).

Nutritional and Medicinal Potential of Lagenariasiceraria . Department of Biosciences, JamiaMillialslamia (Central University), New Delhi, India. Natural.Jávor (eds.), Ajövőélelmiszereiésazegészség, Center-Print Debrece, 198202, ISBN 978-963-9732-36-0.

Madai H. (2008).

A funkcionálisélelmiszerekelőállitása, fogyasztásaéspiaca, [w:] J. Nagy, J. Schmidt, A.

Mattila, P.; J. Astola, and J. Kumpulainen, (2000).

Determination of flavonoids in plant material by HPLC with diode- array detections. J. Agric. Food Chem., 48: 5834-5841.

Upaganlawar, A.and Ramchandran B. (2009).

Bottle gourd (LAGENARIA SICERARIA)"A VEGETABLE FOOD FOR HUMAN HEALTH"- A COMPREHENSIVE REVIEW Pharmacologyonline Department of Pharmacy, Faculty of Technology and Engineering, The Maharaja Sayajirao University of Baroda 390 002, Gujarat1: 209-226. 
Egyptian J. of Nutrition Vol. XXXV No. 1 (2020)

Rahman A.S.H.(2003).

Bottle Gourd (Lagenariasiceraria)-a vegetable for good health .Natural Product Radiance 2(5): 249-250 (2003).

Singleton,V.L. and K .Slinkard,(1977).

Total phenol analysis: automation and comparison with manual methods. American Journal of Enology and Viticulture,28:49-55.

Wettstein, D.V. (1957).

Determination of carotenoids in plants. Experimenal Cell Res., 12, 427-430.

Worrasinchai, S.M. Suphantharika S.Pinjai P. Jamnong.( 2006).

B- Glucan prepared from spent brewer's yeast as a fat replacer in mayonnaise. Food Hydrocolloids,20 (1):68-78. 
Ghada H. H.Ismaiel and Hala M. Z. Ali

الاستفادة من اليقطين الأخضر فى عمل بعض المنتجات الغذائية

غادة حسين حامد إسماعيل هالة محمد زكى على

معهل بحوث تكنولوجيا الأغذية-مركز البحوث الزراعية

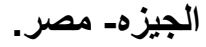

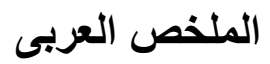

نم إحضار أوراق وثمار نبات اليقطين من معهد بحوث البساتين وتم تحليل أوراق وثمار

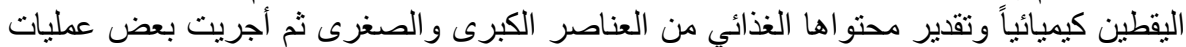

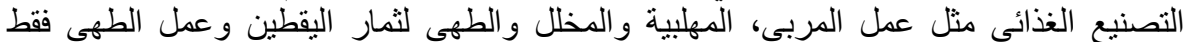
لأوراق اليقطين و ذلك لدراسة الإستفادة منه فى عمل بعض الول الوجبات التغذوية.

ولقتنم إجراء بعض التحاليل منل التقييم الحسي ، التركيب الكيماوي، المحتوى الغذائي

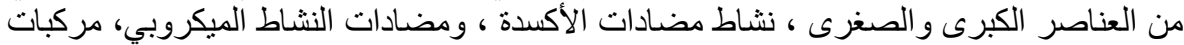
حض الفينوليك، مركبات الفولفنيد للمنتجات التى تم تصنيعها باستخدام اوراق و ثمار اليقطين.

وفيما يلي أهم النتائج المتحصل عليها: مدى تقبل المستهلكين (المحكمين) لمنتجات اليقطين الغذائية أخذ الترتيب التنازلي التالى: أكثر القابلية كان لمربى اليقطين و المشمش بنسبة (1 : ( ) > مخلل اليقطين > مهلبية اليقطين.

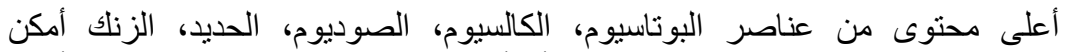

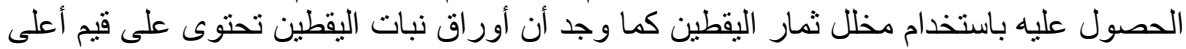

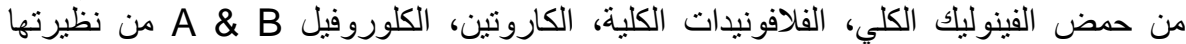

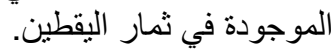

أوراق نبات اليقطين أعطت أعلى القيم لنشاط مضادات النشاط الميكروبي

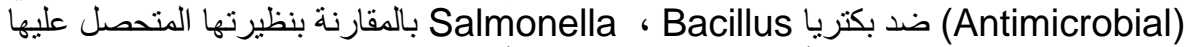
من ثمار اليقطين. ومن جهة أخرى فإن ثمار اليقطين أعطت قيم اعلى لنشاط مضادادات النشاط

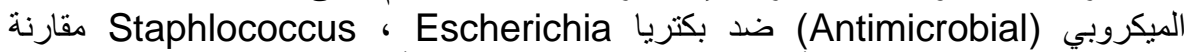
بنظيرتها المتحصل عليها من أوراق نبات اليقطين، وقد وجد أن النيات المكون الرئيسي من مكونات

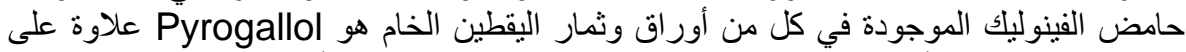

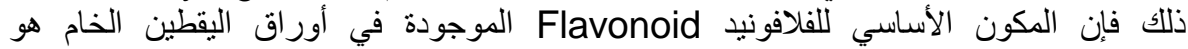
Hespirtin Fespirdin

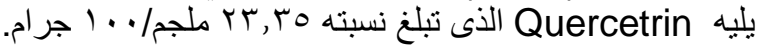

و عليه فأن هذة الدراسة توصى بالاستفادة من اوراق و ثمار اليقطين و ادخاله فى بعض الاغذية و ذلك لتغزيز ها بالعناصر الغذائية النادره و كمضادات لكنات للاكسدة و الميكروبات. 